\title{
Os gêneros orais na penúltima versão da Base Nacional Comum Curricular: implicações para o ensino
}

\author{
Ana Elisa Jacob* \\ Kátia Diolina** $^{* *}$ \\ Luzia Bueno***
}

\begin{abstract}
Resumo
Este artigo objetiva discutir os conteúdos configurados na penúltima versão da Base Nacional Comum Curricular de 2017, particularmente, aqueles referentes ao trabalho proposto com os gêneros orais no ensino de Língua Portuguesa nos anos finais do Ensino Fundamental. Para tanto, assumimos o quadro teórico-metodológico do Interacionismo Sociodiscursivo e da Didática das Línguas Genebrina, bem como os referenciais da Clínica da Atividade sobre a atividade de trabalho, os estudos do grupo ERGAPE sobre o trabalho docente e a perspectiva freireana do currículo como instrumento de ação política e pedagógica. Os resultados apontam para a falta da participação do professor atuante na elaboração da mesma, bem como para a ausência de diretrizes que privilegiem o diálogo, a criticidade, a interação social do aluno por meio do ensino dos gêneros orais.

Palavras-chave: Currículo; Gêneros Orais; Trabalho Docente; Ensino de Língua Portuguesa.
\end{abstract}

The oral genres in the penultimate version of the Common Curricular National Base: implications for the teaching

\begin{abstract}
This paper aims to discuss the contents that were altered at the penultimate version of the 2017 Common Curricular National Base, especially those that refer to the proposed work with the oral genres when teaching Portuguese to the latest years of Elementary School. In order to do so, we have resorted to the theoretical and epistemological framework of the Socio-Discursive Interactionism and of the Didactics of Languages of Geneva; and also to the Clinic of Activity's references on the working activity, to the ERGAPE's studies on the teaching work and to the Freirean perspective on the curriculum as an instrument of political and pedagogical action. The results indicate the lack of involvement of teachers in its elaboration, as well as the absence of guidelines that fosters the dialogue, the critical thinking, the social interaction of the student through the teaching of oral genres. Keywords: Curriculum; Oral Genres; Teaching Work; Teaching of Portuguese language.
\end{abstract}

\section{Introdução}

Neste artigo, objetivamos discutir os conteúdos configurados na penúltima versão da Base Nacional Comum Curricular de 2017, particularmente, aqueles referentes ao trabalho proposto com os gêneros orais no ensino de Língua Portuguesa nos anos finais do Ensino Fundamental.

Compreendemos que toda Base Nacional Comum Curricular (doravante BNCC) pode exercer um papel norteador quanto aos conteúdos contemplados nas instituições escolares, o que traz implicações diretas tanto nas ações empregadas pelos professores como no processo de desenvolvimento dos educandos. Trata-se de um texto normativo de caráter político e, consequentemente, ideológico que exerce a função de legitimar determinados conhecimentos em detrimento de outros. A versão analisada neste artigo não corresponde a que fora homologada em

* Endereço Eletrônico: ana.elisa.jacob@gmail.com

*** Endereço Eletrônico: katiadio@gmail.com

**** Endereço Eletrônico: luzia.bueno@usf.edu.br dezembro de 2017, mas é a anterior a oficial. Consideramos que entender e discutir os conhecimentos privilegiados nessa versão, contribui para que outras pesquisas, centradas na BNCC homologada, possam melhor compreender a história de construção e de transformação das propostas inseridas nesse documento.

Dessa forma, nossa proposta é, portanto, problematizar sobre as implicações para o ensino dos gêneros orais, na disciplina de Língua Portuguesa, nos anos finais do Ensino Fundamental, nesse documento em construção, que se configura como norteador para determinadas tomadas de decisão e reação da educação brasileira. Ressaltamos que assumimos os gêneros orais ou escritos como instrumentos de ação e de transformação dos modos de agir prático e comunicacional, daí a importância de nos centrarmos nesses conteúdos.

Para tanto, este artigo integra e baseia-se 
nos conhecimentos desenvolvidos pelo grupo ALTER-LEGE (Análise da Linguagem, Trabalho e suas Relações - Letramento, Gêneros Textuais e Ensino), que se preocupa em contribuir com novas perspectivas teórico-metodológicas acerca dos processos de letramento, de ensino e do ensino de gêneros textuais. O ALTER-LEGE filia-se e contribui com o grupo maior ALTER-CNPq, com sede na Universidade de São Paulo, que, desde os anos 90, interessa-se pela Análise da Linguagem, o Trabalho Educacional e suas Relações num diálogo profícuo com os referenciais do Interacionismo Sociodiscursivo (BRONCKART, 1999; MACHADO; BRONCKART, 2009); do grupo ERGAPE - (Ergonomie de l'activité des professionnels de l'éducation), do Institut de Formation de Maîtres de Marseille e Universidade de Aix-Marseille (AMIGUES, 2004; SAUJAT, 2004); da equipe da Clínica da Atividade (CLOT, 2006; 2010), vertente da Psicologia do Trabalho do Conservatoire National des Arts et Métier - CNAM de Paris; bem como das concepções de currículo desenvolvidas pela perspectiva freireana de educação enquanto prática emancipatória (MENEZES; SANTIAGO, 2014).

Ressaltamos que dividimos este artigo em quatro seções. A primeira refere-se aos estudos sobre a importância dos gêneros textuais enquanto megainstrumentos, particularmente, os gêneros orais. Na segunda seção, discutimos as implicações de textos normativos, como a penúltima versão da BNCC, no desenvolvimento da atividade de trabalho (a do professor), bem como defendemos nossa concepção de currículo. Na terceira seção, desenvolvemos nossas análises e interpretações, procurando problematizar os dados no documento discutido. Finalmente, na quarta seção, destacaremos nossas considerações finais.

\section{Os gêneros orais: megainstrumentos para o ensino}

Nesta seção, a proposta é discutir os gêneros textuais e sua importância como megainstrumentos (DOLZ; SCHNEUWLY, 2004) no desenvolvimento das capacidades de linguagem dos estudantes, em especial, por meio dos gêneros orais.

Gênero textual é a forma a que se recorre para produzir um texto concreto em uma atividade de linguagem desenvolvida num dado momento histórico, social e cultural, por determinados interlocutores (produtor/destinatário) em razão dos efeitos que almejam, ou mesmo, que estão implicados e ainda dos meios que dispõem ou não. Para Schneuwly e Dolz (2004, p. 74), "é através dos gêneros que as práticas de linguagem materializamse", servindo "como um modelo comum, como uma representação integrativa que determina um horizonte de expectativas para os membros de uma comunidade" (SCHNEUWLY; DOLZ, 2004, p.74). Volochinov (1986) esclarece que

não basta colocar face a face dois homo sapiens quaisquer para que os signos se constituam. É fundamental que esses dois indivíduos estejam socialmente organizados, que formem um grupo (uma unidade social): só assim um sistema de signos pode constituir-se. A consciência individual não só nada pode explicar, mas, ao contrário, deve ela própria ser explicada a partir do meio ideológico e social (VOLOCHINOV, 1986. p. 35).

Para o autor, a palavra é ideológica e socialmente constituída, transformada, interpretada, compreendida por meio dos gêneros textuais. Eles consistem em tipos relativamente estáveis de enunciados que exercem uma função social: são modelos do dizer que veiculam, legitimam, avaliam, interpretam modelos do fazer, do se comportar, do ser etc. "Assim, a análise de gêneros engloba uma visão da sociedade. Os gêneros são uma forma de ação social e um artefato cultural importante como parte integrante da estrutura comunicativa de nossa sociedade" (MARCUSCHI, 2008, p. 149, grifo do autor).

Nesse sentido, Schneuwly (2004) defende que o gênero, seja oral seja escrito, "pode ser considerado um instrumento psicológico no sentido vigostkiano do termo" (SCHNEUWLY, 2004, p. 22). Na perspectiva vigotskiana, o instrumento pode ser técnico ou psicológico, conforme a direção de sua ação (RABARDEL, 2002). O direcionamento da ação de um instrumento técnico, por exemplo, atua como mediador entre os objetos do mundo e a atividade do sujeito. Já o do psicológico se endereça ao psiquismo, isto é, ao comportamento humano, a uma "atividade endereçada a si mesmo e não ao objeto" (RABARDEL, 2002, p. 268). Nas palavras de Machado (2010), o instrumento psicológico atua como ampliador e mediador de nossas capacidades, graças "a apropriação pelo e para o próprio sujeito" (MACHADO, 2010, p. 164, grifo da autora).

O processo de apropriação é complexo e envolve artefatos e instrumentos. Os artefatos estão em números incalculáveis e disponíveis em nossa sociedade, a saber: os gêneros textuais (carta, 
seminários, debates, notícias etc.), lousa, giz, computador etc. Entretanto, para que esses artefatos recebam o estatuto de instrumento, eles devem sofrer um processo de apropriação. Para Rabardel (1995),

o processo de apropriação de um artefato é acompanhado, conforme o sujeito, de construções representativas relativas ao instrumento e à realidade (...) é acompanhado também da elaboração de estruturas permitindo a organização da ação do sujeito: os esquemas de utilização (RABARDEL, 1995, p. 63, tradução e adaptação nossa1).

Para Schneuwly (2004), os "esquemas de utilização" ocorrem em um processo no qual o sujeito, na relação com o artefato, elabora, reelabora, articulando as possibilidades de uso em virtude da situação de ação e dos objetivos que se tem (SCHNEUWLY, 2004, p. 24). Dito de outra forma, tornar instrumento é ampliar a capacidade de ação humana (pelo homem) de acordo com as suas necessidades (para o homem), o que o caracteriza também como meio mais permanente e disponível para as ações futuras (RABARDEL, 1995). Diolina (2016), pautada nesses estudos, esclarece que se trata de um processo dialético, em que os elementos estão sempre numa relação tríade e conflituosa entre artefatos, sujeito e esquemas/padrões de utilização associados ao próprio sujeito e ao contexto sóciohistórico. Dessa forma, esse processo consiste em desenvolvimento do indivíduo, pois promovem no sujeito "construções representativas referentes ao instrumento em virtude do para quê que se destina a ação, numa dada situação, com determinado objetivo, para ampliar, estender suas próprias capacidades" (MACHADO, 2010, p. 164, grifo da autora).

Com base nesses estudos, Dolz e Schneuwly (2004), em colaboração com Sylvie Haller, sustentam que os gêneros textuais não seriam apenas instrumentos, mas sim "megainstrumentos, visto que podemos considerálos como a integração de um grande conjunto de instrumentos num todo único" (DOLZ; SCHNEUWLY, 2004, p. 174, grifo dos autores). Esse conjunto de conhecimentos envolve a maestria da situação de comunicação o que implica conhecimentos relativos ao tema, às finalidades e aos possíveis destinatários, num processo de desenvolvimento das capacidades de linguagem dos sujeitos. Nesse processo, diferentes capacidades são evocadas e apreendidas, como: (i) a capacidade de ação (adequação quanto aos aspectos relativos ao contexto); (ii) a capacidade discursiva (recorrer a modelos discursivos) e (iii) a capacidade linguístico-discursiva (domínio das operações psicolinguísticas e das unidades linguísticas). Sendo assim, os gêneros textuais, ao serem apropriados, tornam-se megainstrumentos do indivíduo e dos membros da comunidade em que se inserem, pois exigem a mobilização de diferentes conhecimentos sócio-histórico e culturalmente desenvolvidos.

Com os gêneros orais, não é diferente. Marcuschi (2008, p.194-196) defende e elenca uma série de gêneros orais próprios de diferentes esferas discursivas, a saber: a instrucional (conferências, exposições, colóquios, defesas de mestrados/doutorado, etc.); a jornalística (entrevistas, notícias de rádio e tv, apresentações, boletim do tempo, etc.); a religiosa (sermões, lamentações, confissões); a comercial (publicidade de feira, de tv e de rádio, refrão de carro de venda de rua etc.); a industrial (reuniões, ordens etc.); a jurídica (depoimento, inquérito judicial, ordem de prisão etc.), entre outras. $\mathrm{O}$ que se evidencia é a imensa variedade de gêneros orais e sua importância enquanto práticas socialmente inseridas $\mathrm{e}$ organizadas nas diversas esferas discursivas, de modo a concretizar formas de comunicação, bem como estratégias de compreensão nas interações "que se transmitem de geração para geração com propósitos e efeitos definidos e claros. [Acarretando] formas de ação, de reflexão e avaliação social (...) e também de organização das relações de poder" (MARCUSCHI, 2008, p. 194).

Marcuschi (2003) esclarece que o homem, a partir de sua especificidade, é um ser que fala, todavia a fala implica em peculiaridades dependentes de conhecimentos que ultrapassam os meios linguísticos, recorrendo aos não-linguísticos, num processo de construção de sentidos envolvendo mímicas faciais, olhares, gestos, tom da voz etc. Para Dolz, Schneuwly e Haller (2010) os meios não-linguísticos organizam-se em cinco tipos: (i) meios paralinguísticos (corresponde à qualidade da voz, melodia, elocução e pausas, respiração, risos e suspiros); (ii) meios cinésicos (corresponde ao uso dos gestos, atitudes corporais, os movimentos, troca de olhares, mímicas faciais, de maneira racional e adequado ao contexto e conteúdo da mensagem); (iii) posição dos locutores (corresponde à ocupação de lugares, espaço pessoal, distâncias e contato físico); (iv) aspecto exterior (consiste em roupas, disfarces, penteado, óculos, acessórios); e (v) disposição dos lugares (corresponde a análise dos 
lugares, disposição dos móveis e objetos presentes no ambiente em que ocorrem a comunicação, a iluminação, decoração e ventilação).

Logo, há uma complexidade que envolve os gêneros orais em razão dos elementos linguísticos e não-linguísticos próprios do ato comunicativo nas diversas situações, o que exige um controle consciente e voluntário do indivíduo em relação aos modos de dizer conforme as restrições impostas pelo exterior. Dolz e Schneuwly (2010) postulam que a unicidade de tempo e lugar do processo de produção do texto oral ouvido pelos interlocutores requer dos locutores a realização integral de todas as dimensões da comunicação de uma única vez, isto é, exige uma resposta em tempo real, uma capacidade de prever, de antever, de construir, de coconstruir um texto, enquanto unidade de sentido, que atinja os objetivos de uma comunicação específica. Daí a importância de ensinar os gêneros orais, de modo que se tornem megainstrumentos em prol de um maior poder de agir dos indivíduos nas diferentes interações. Mas como os textos prescritivos e normativos orientam o processo de ensino dos mesmos? Questão que tratamos a seguir.

\section{As prescrições: implicações na atividade docente}

Para compreendermos o papel das prescrições enquanto norteador das condutas humanas, é fundamental salientar que o agir comunicacional, realizado por meio dos gêneros textuais, regula o agir praxiológico (prático). Em outros termos, os parâmetros que orientam as condutas humanas (o agir prático) são produzidos nas interações por meio da linguagem (agir comunicacional), isso ocorre quando é "estabelecido entre os interactantes um entendimento ou um acordo sobre o que são as situações nas quais se desenrola a atividade" (BRONCKART, 2006, p. 73) e esse acordo ou intercompreensão necessária dá-se a partir do agir comunicacional.

Para Bronckart (2017a), "a unidade de análise é a ação mediada pela linguagem: uma sequência organizada de eventos imputáveis a um agente do qual podem ser atribuídos motivos (representações retroativas das razões do agir) e intenções (representações proativas do efeito da ação) (BRONCKART, 2017a p. 33, tradução nossa ${ }^{2}$ ). Por meio do agir comunicacional estabelecemos, portanto, acordos sobre os meios e os modos do agir prático em um determinado contexto, de maneira que possamos avaliar, interpretar e imprimir significados às condutas humanas, atribuindo a elas motivos, intenções, bem como recursos ao se realizarem.

Com os textos prescritivos ocorre o mesmo processo, em que o objetivo consiste em orientar, direcionar, instruir sobre os modos de fazer uma determinada atividade. Dessa forma, os gêneros prescritivos (regras de jogos, manuais de montagem, receita médica, leis, resoluções, diretrizes, parâmetros etc.) exercem uma função social de instruir, bem como a de legitimar determinadas ações em detrimento de outras, como, a Base Nacional Comum Curricular.

A prescrição deve ser compreendida como a "tarefa, o que deve ser feito e o que pode ser objetivamente descrita em termos de condições e de objetivo, de meios (materiais, técnicos...) utilizados pelos sujeitos" (AMIGUES, 2004, p.39, grifo do autor), ou seja, consiste nas normas, nas regras de como deve ser executado determinado trabalho. Para Clot (2006), as prescrições são as memórias de diferentes iniciativas de trabalhadores ao longo do tempo.

Particularmente, todo trabalho é impessoal, pois é regido e guiado por normas, regras de conduta, mas também é pessoal, visto que é realizado por um sujeito; bem como é interpessoal, já que é realizado para e com outras pessoas; além de ser transpessoal, uma vez que implica modos de agir próprios da profissão, que foram configurados ao longo da história.

Dessa forma, as prescrições constituem todo trabalho e, enquanto textos, norteiam, orientam a atividade de trabalho, bem como legitimam as ações possíveis e as impedidas. Embora a prescrição seja norteadora, existe um hiato entre a tarefa dada e a atividade realizada, pois o trabalhador, ao recorrer às normas de conduta de sua profissão, readéqua-as conforme as possibilidades de realização em situação de trabalho. Para Clot (2006), esse processo possibilita o desenvolvimento em razão das contradições existentes no real da atividade. Nas palavras do autor, "a atividade de trabalho consiste em ultrapassar as contradições existentes - jamais totalmente previsíveis - que põe o sujeito em contato com as realidades objetivas do mundo das coisas e dos homens, ocasiões para e obstáculo ao seu desenvolvimento" (CLOT, 2006, p. 93). Nesse processo de readequação, de transformação, de realização, a atividade de trabalho configura-se como "uma arena, o teatro de uma luta [em que] aparecem os pontos de colisão entre vários desenvolvimentos possíveis (CLOT, 2006, p. 99).

Esse conflito ocorre na relação entre três 
polos que constituem toda atividade de trabalho, como a do professor. A atividade então se dirige ao próprio profissional, fonte da ação humana no trabalho (o professor), que precisa organizar o meio/ambiente (o objeto) em prol diretamente do ensino e aprendizagem de seus alunos (o outrem) e, indiretamente, em "acordo" com a comunidade, com os demais colegas de profissão, com os gestores, funcionários da escola etc., que também constituem o outrem. Sendo que esse processo pode ser mediado por instrumentos materiais e simbólicos (lousa, giz, textos, data show) disponíveis ou não. Além disso, a atividade docente está inserida num contexto social, histórico e cultural maior e outro específico, o da situação de trabalho, bem como se configura a partir de um sistema de ensino e educacional próprios de resoluções, leis, parâmetros, diretrizes e objetivos políticos.

Devemos compreender que

os professores em trabalho tecem, eis os fios que os ligam aos programas e instruções oficiais, às ferramentas pedagógicas, às políticas educacionais, às características dos estabelecimentos e dos alunos, às regras formais, ao controle exercido pela hierarquia (...) ei-los ligados a sua própria história, a seu corpo que aprende e envelhece; a uma imensa quantidade de experiências de trabalho e de vida; a vários grupos sociais que lhes oferecem saberes, valores, regras às quais se ajustam dia após dia; a seus familiares também, fontes de energia e de preocupação; a projetos, desejos, angústias, sonhos... (DANIELLOU, 1996 apud SAUJAT, 2004, p. 29).

Entretanto, Amigues (2004) alerta que "a ação do professor é naturalmente considerada do ponto de vista prescritivo ou normativo da instituição" (AMIGUES, 2004, p. 37). Em outras palavras, o trabalho do professor resume-se a realizar tarefas, como, onde e quando deve fazer e o que deve ser feito. Despreza-se, assim, as capacidades, a formação, as trocas com os colegas, o processo de desenvolvimento natural que é construído e vivido pelo professor no exercício de sua atividade. Diolina (2017) alerta que "as trocas, as observações, as avaliações entre o indivíduo e o coletivo são essenciais para o desenvolvimento e para a transformação do gênero profissional" (DIOLINA, 2017, p. 439), de modo que se tornem meio para o poder de agir de cada um (CLOT, 2010).

É nesse sentido que questionamos o papel das prescrições, em particular da Base Nacional
Comum Curricular, que tem o objetivo de instruir sobre os conteúdos a serem contemplados, ou mesmo, os que serão abandonados, descartados. Menezes e Santiago (2014), fundamentadas nos estudos freireanos, alertam que o currículo deve ser um objeto de construção coletiva, em que o diálogo seja o princípio norteador para uma proposta de currículo crítico-emancipatório. Em outros termos, devemos pensar o currículo enquanto instrumento de ação política e pedagógica, que permita aos educandos reconhecer e desvelar a realidade criticamente, num processo de ação consciente e criadora.

Para tanto, segundo as autoras, o currículo deve garantir "conhecer o que não conhecem; conhecer melhor o que já conhecem; e conhecer melhor como construir seu próprio conhecimento" (MENEZES; SANTIAGO, 2014, p. 55). Assim, o currículo torna-se um instrumento de consciência da realidade e de si, do papel de estar e de transformar, de criar e recriar a realidade. Isto posto, o currículo não deve ter um caráter altamente técnico e linear, verticalizado e impositivo sobre quais conteúdos devem ser priorizados em detrimento de outros. É nesse sentido que a teoria freireana defende o currículo como instrumento de ação política, já que nele é legitimado: determinados conteúdos em prol de quem/do quê, contra o quê/quem. O currículo, portanto, não pode se limitar a fragmentos de uma única realidade, mas sim deve possibilitar uma ampla visão, permitir a problematização em prol da práxis que transforma a realidade e que permite ao homem encontrar seu significado enquanto agente cocriador de seu mundo.

Daí a importância de discutir o papel do currículo na atividade de trabalho do professor, particularmente, dos conteúdos relativos aos gêneros orais, já que também os assumimos como instrumentos da ação consciente e significativa dos indivíduos no mundo, conforme segue.

\section{Penúltima versão da BNCC e os Gêneros Orais nos anos finais do Ensino Fundamental}

Em conformidade com o quadro teóricometodológico a que nos filiamos, o Interacionismo Sociodiscursivo, as análises de quaisquer textos, sejam eles de orientação para o trabalho didático ou para a compreensão do agir humano, devem partir sempre do contexto de produção e depois votar-se para a arquitetura interna do texto (BRONCKART, 1999, 2008, 2009, 2017b). Tal procedimento metodológico deve-se à teoria de Volochinov 
(1986) sobre o estatuto ideológico do signo linguístico, que adquire essa adjetivação devido às estreitas e determinantes relações com a realidade em que está inserido "Um signo não existe apenas como parte de uma realidade; ele também reflete e refrata uma outra. Ele pode distorcer essa realidade, ser-lhe fiel ou apreendê-la de um ponto de vista específico, etc." (VOLOCHINOV, 1986. p. 32).

Além da orientação analítica para o contexto, Volochinov (1986) postula que ela também deve se direcionar aos conteúdos, em outras palavras, aos temas que se atualizam num dado momento do tempo, aos objetos que recebem a atenção do corpo social e que, por esse motivo, tomam um valor particular. Tais objetos temáticos eleitos, constituídos, e valorizados socialmente, tornam-se signos da comunicação ao estabelecerem relações estreitas com as condições socioeconômicas do grupo, desencadeando, assim, uma reação semiótico-ideológica. Volochinov (1986) acrescenta, por último, aos critérios de análise, os tipos e formas de discurso pelos quais os temas "tomam forma, são comentados, se realizam, são experimentados, são pensados, etc." (VOLOCHINOV, 1986. p. 42), ou seja, as formas materiais precisas da expressão social. Segundo o filósofo, o contexto, o tema e as formas materiais e estruturantes do discurso convivem e devem ser analisados, segundo essa perspectiva, de modo dialético:

A cada grupo de formas pertencentes ao mesmo gênero, isto é, a cada forma de discurso social, corresponde um grupo de temas. Entre as formas de comunicação (...), a forma de enunciação (...) e enfim o tema, existe uma unidade orgânica que nada poderia destruir. Eis porque a classificação das formas de enunciação deve apoiar-se sobre uma classificação das formas da comunicação verbal (VOLOCHINOV, 1986. p. 43, grifos do autor).

Dessa forma, para a análise do texto da penúltima versão da BNCC e das seções destinadas à explanação dos Fundamentos Pedagógicos, das propostas para o ensino de Língua Portuguesa e da etapa dos anos finais do Ensino Fundamental, partimos, primeiramente, do contexto de produção, para depois chegarmos à organização do conteúdo temático, além das formas lexicais, que fundamentarão nossas interpretações e discussões desse documento.

O contexto social em que a versão em questão da BNCC é construída consiste em um momento político-econômico brasileiro bastante caótico. O ano de 2016 é marcado por intensas manifestações sociais que culminaram no Impeachment da presidente Dilma Roussef. Com a posse do vice-presidente, Michel Temer, há a alteração do plano de governo e a elaboração de novas normatizações trabalhistas e previdenciárias, dentre outras demandas. Concomitantemente, crimes de corrupção são julgados e amplamente divulgados na grande mídia. $\mathrm{O}$ discurso da crise financeira prevalece em todos os setores sociais. Enfim, há um clima de instabilidade que, por conseguinte, acarreta em mudanças extremas na vida dos brasileiros, principalmente, na dos trabalhadores. A BNCC, desse modo, assim como quaisquer textos, não escaparia aos reflexos e refrações dessas situações.

Em relação ao intertexto com o qual a BNCC dialoga, verificamos que há influências da Constituição Federal de 1988, das Leis das Diretrizes de Base da Educação (doravante LDB), das Diretrizes Curriculares Nacionais da Educação Básica e do Plano Nacional de Educação (doravante PNE) de 2014. Tais textos, conforme o próprio documento atesta, em especial a LDB e o PNE, são retomados para a produção do efeito de legalidade da necessidade de uma base comum curricular a todas as instituições escolares, bem como para a justificativa da "pactuação interfederativa".

Apesar da aparente sustentação legal apresentada pela BNCC, há de se verificar que a exigência da participação do governo e da sociedade no processo de elaboração de bases comuns para educação, mencionada tanto pela LDB quanto pelo PNE, não é efetivamente cumprida como defende Freitas (2017), instituindo um conflito entre diferentes setores sociais. Freitas (2017) discute esse dissenso constatando que, de um lado, está o governo federal defendendo os interesses de grupos que buscam a padronização do ensino com a finalidade de negociar formas de ensino, de avaliação e de materiais didáticos para a escola pública; e, de outro lado, estão os pesquisadores ligados à ANFOPE (Associação Nacional pela Formação dos Profissionais em Educação) defendendo uma construção conjunta e considerando os interesses locais/nacionais.

O conflito ainda se mostra na elaboração de quatro versões da BNCC, sendo as duas primeiras amplamente discutidas pela sociedade, por meio de associações e universidade, como bem frisaram Cordeiro (2017), Rojo (2017) e Bueno, Jacob e Zani (2017 - no prelo); a terceira versão, publicada em 
abril de 2017 e analisada neste artigo, que desconsidera esse diálogo plural das instituições representantes da educação brasileira e divulga propostas elaboradas por um grupo seleto de governantes e empresários; e a última, a quarta versão homologada em dezembro de 2017, que aparenta retomar as discussões propostas nas primeiras versões, incluir temáticas importantes como os direitos humanos, a desigualdade social e o respeito e aprendizado das culturas afrodescendentes e indígenas, por exemplo, além de resgatar a imprescindibilidade da adequação do currículo às inúmeras e diversas realidades brasileiras.

A tese de que há um favorecimento de um grupo no debate das ideias que constam na penúltima versão da BNCC pode ser comprovada quando analisamos o contexto mais imediato de produção: os enunciadores e os destinatários. Segundo as informações obtidas na introdução do documento, o órgão responsável pela elaboração é o governo federal em interlocução com a sociedade. Contudo, na contracapa, são nomeados os prováveis produtores do texto (Ministério da Educação, Ministro de Estado da Educação, Secretaria Executiva, Secretaria de Educação Básica), seus parceiros (Conselho Nacional de Secretários de Educação - CONSED, e União Nacional dos Dirigentes Municipais de Educação - UNDIME) e seus apoiadores (Movimento pela Base). Destarte, não foi encontrada nesse grupo nenhuma referência a pesquisadores, ou professores, ou ainda associações e sindicatos destes.

Continuando a investigação do contexto mais imediato de produção, ao acessarmos o site do Movimento pela

Base

(http://movimentopelabase.org.br/quem-somos/)

com o intuito de verificarmos quem seriam os membros desse grupo, vários institutos foram identificados como Fundação Lemann, Fundação Roberto Marinho, Instituto Inspirare, Instituto Unibanco, Instituto Natura, Itaú BBA, entre outros, havendo, dentre eles, apenas duas pessoas cuja função era ser professor - Egon Rangel da PUC-SP e Magda Soares da UFMG; constatamos também que as demais pessoas mencionadas ou têm cargos de gestores nos institutos ou nos governos federal ou estadual. É válido frisar que, na quarta versão homologada, esses apoiadores não aparecem como participantes da elaboração da BNCC, transparecendo um possível conflito de ideias e ideais para a educação brasileira.

Podemos ver, portanto, que há, na penúltima versão da BNCC, um grupo de pessoas cuja voz é levada mais em consideração: as empresas privadas. Apesar de considerarmos a participação desse setor importante para a educação, verifica-se que há o desprestígio dos próprios profissionais da educação que receberão as prescrições e terão de adequá-las às suas ações diárias, o que reduz o papel do professor e reforça a ideia que seu trabalho é, na verdade, a aplicação de métodos e de conteúdos. Uma tarefa, uma receita dada que deve ser realizada, num reducionismo absurdo da complexidade que constitui a docência.

Como bem nos lembra Alves (2014), para o professor, haveria intervenções governamentais mais significativas nas diferentes realidades educacionais do que uma BNCC como, por exemplo, a melhoria nas condições de trabalho, salariais e de infraestrutura das escolas. Machado e Bronckart (2009), ao analisarem as prescrições educacionais suíça e brasileira, no último caso os Parâmetros Curriculares Nacionais (doravante PCN), já nos alertavam para esses modos de intervenção nas práticas escolares ao afirmarem que, muitas vezes, supõe-se que a melhoria da qualidade educacional estaria na elaboração de novas diretrizes para o trabalhador, quando, na verdade, ouvi-lo seria um bom caminho para compreender os sucessos e insucessos educacionais.

Tal disparidade de representatividade participativa entre o governo, as empresas privadas e a sociedade fica ainda mais manifesta e contraditória quando identificamos os propósitos assumidos na penúltima versão da BNCC: formação humana integral para a construção de uma sociedade mais justa, democrática e inclusiva (Figura 1). Como atingir esses propósitos, se nem mesmo a realidade da escola, das condições de trabalho dos professores e os saberes construídos na e pela prática educacional estão sendo privilegiados? 
FIGURA 1: Propósitos pedagógicos assumidos pela penúltima versão da BNCC A Base Nacional Comum Curricular

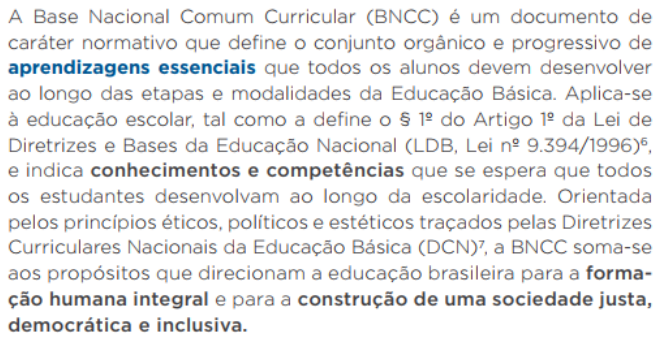

Fonte: BNCC, p. 7. Disponível em http://basenacionalcomum.mec.gov.br/images/BNCC_publicacao.pdf Acesso $16 / 10 / 2017$

Vemos, portanto, que os princípios assumidos assemelham-se à perspectiva democrática e inclusiva curricular freiriana, no entanto, quando a elaboração do documento em análise se faz unilateralmente, contemplando apenas uma pequena parte da sociedade - representantes do governo e empresas privadas - impõe-se uma contradição. Inviabiliza-se, dessa forma, a problematização da própria práxis visada por aqueles que estão inseridos diariamente nela: os profissionais de educação.

No tocante ao Plano Global, o documento tem, no total, 396 páginas, incluindo-se a capa e contracapa. Divide-se em cinco partes: Apresentação (não numerada); 1. Introdução; 2. A estrutura da BNCC; 3. A etapa da Educação Infantil; 4. A etapa do Ensino Fundamental. Na seção 4, há uma divisão por área, que se subdivide em disciplinas. Há a área de Linguagens (Língua Portuguesa, Artes, Educação Física e Língua Inglesa), de Matemática, de Ciências da Natureza e de Ciências Humanas (Geografia e História). Logo no início de cada disciplina ou área, há a apresentação das competências esperadas. Além disso, também são abordados, separadamente, os conteúdos destinados aos anos iniciais e aos anos finais desse período de ensino, acompanhados de seus respectivos conhecimentos e habilidades.

Como nosso foco é o ensino de gêneros orais, selecionamos, para uma análise mais minuciosa, as seções e subseções que constam: os Fundamentos Pedagógicos da penúltima versão da BNCC; as prescrições para a etapa dos anos finais do Ensino Fundamental; as propostas para o ensino de Língua Portuguesa e, de modo específico, aquelas que tangem aos anos finais do Ensino Fundamental. Tal conjunto de informações apresenta-se relevante, uma vez que podem tornar claros, como nos esclarecem Schneuwly e Dolz
(2010): os princípios teóricos que sustentam a proposta; as concepções dos sujeitos de ensino e de aprendizagem adotados; os conhecimentos que se propõem a ensinar e as justificativas para sua seleção; os objetivos dessa proposta, e a coerência entre $o$ que se considera relevante para o aprendizado e o que, de fato, se privilegia e prescreve para o ensino.

$\mathrm{Na}$ Introdução, na seção em que são expostos os Fundamentos Pedagógicos da penúltima versão da BNCC, encontrados nas páginas de 15 a 19, na primeira subseção intitulada como $O s$ conteúdos curriculares a serviço do desenvolvimento de competências, fica clara a seleção das competências como norteadoras para todos os currículos brasileiros. A definição de competências é depreendida no excerto "A esse conhecimento mobilizado, operado e aplicado em situação se dá o nome de competência." (BNCC, 2017, p. 15. grifo do documento). Podemos inferir através dessa definição, que é esperado que os alunos, com as novas investidas da BNCC, após passarem por todas as etapas da Educação Básica, sejam capazes de três ações principais: mobilizar os conhecimentos, supostamente aprendidos na escola, operá-los (ação que não evidencia se é no nível cognitivo ou motor) e aplicá-los nas situações vividas. Questionamos, entretanto, se essas ações são suficientes para que nossos alunos possam agir em diferentes contextos de modo a vislumbrar sua formação integral e a formação de uma sociedade mais democrática, justa e inclusiva como declarado no documento. Estaremos, de fato, auxiliando na educação crítica de nossos alunos assumindo essa missão educadora de desenvolver competências, em que é esperado que ele "aplique" conhecimentos? Nesse sentido, não há uma preocupação que o aluno seja atuante, pois não se espera que ele crie e recrie novos conhecimentos, somente que "aplique". Mais 
uma vez, agora em relação à formação do estudante, percebemos um reducionismo das capacidades de desenvolvimento possíveis.

Para sustentar a defesa central das competências, a penúltima versão da BNCC recorre à voz normativa, representada pelas LDB, em seus artigos $9 .^{\circ}, 32 .^{\circ}, 35 .^{\circ}$ e $36 .^{\circ}$, e às vozes dos órgãos avaliativos internacionais: Organização para a Cooperação e Desenvolvimento Econômico (OCDE), Programa Internacional de Avaliação de Alunos (Pisa), Organização das Nações Unidas para a Educação, a Ciência e a Cultura (Unesco, na sigla em inglês), e o Laboratório Latino-americano de Avaliação da Qualidade da Educação para a América Latina (LLECE, na sigla em espanhol). Verificamos que, ao retomar tais vozes sociais para legitimar a centralização do desenvolvimento das competências, essa versão da BNCC institui uma verdade incontestável, amplamente divulgada e aceita pela própria educação brasileira, desde a década de 1990, e pelos órgãos internacionais preocupados com os resultados de aprendizagem demonstrados nas avaliações externas. Assim como outrora, como vimos na análise do contexto de produção, não são retomadas as vozes de especialistas da educação, das universidades e dos próprios envolvidos com a ação de ensinar, os professores. Assumem-se, portanto, as competências como objetos de ensino sem recorrer a estudos já desenvolvidos e que podem revelar, ou não, os bons resultados de ensino-aprendizado por esse viés, uma vez que essa lógica educacional já vem sendo implantada não só no Brasil, mas em boa parte dos países da América Latina há duas décadas.

Ainda nesse momento de exploração das competências, o tom prescritivo de seu ensino fica evidente com a utilização das expressões deônticas "devem saber" e "devem saber fazer"; com o uso, em locuções verbais, do presente, no verbo auxiliar, e do infinitivo, no verbo principal, como em "vem reafirmar"; e com os usos de expressões pertencentes ao campo semântico do direito/dever "com a garantia de que os direitos da aprendizagem sejam assegurados", "assegurem esses direitos"; como visto no trecho a seguir (Figura 2):

FIGURA 2: As competências na penúltima versão da BNCC

$$
\begin{aligned}
& \text { A adoção desse enfoque vem reafirmar o compromisso da BNCC } \\
& \text { com a garantia de que os direitos de aprendizagem sejam assegura- } \\
& \text { dos a todos os alunos. Com efeito, a explicitação de competências } \\
& \text { - a indicação clara do que os alunos devem saber, e, sobretudo, } \\
& \text { do que devem saber fazer como resultado de sua aprendizagem - } \\
& \text { oferece referências para o fortalecimento de ações que assegurem } \\
& \text { esses direitos. }
\end{aligned}
$$

Fonte: BNCC, p. 16. Disponível em http://basenacionalcomum.mec.gov.br/images/BNCC_publicacao.pdf Acesso 16/10/2017

A segunda subseção dos Fundamentos Pedagógicos da penúltima versão da BNCC, intitulada como $O$ compromisso com a educação integral, esclarece que esse tipo de educação não está vinculado à educação de período integral, mas com a integridade humana. Como veremos a seguir, esse compromisso destoa da lógica do ensino pelas competências, do mobilizar conhecimento e aplicálos, pois, para uma educação que busca contemplar as situações que envolvem o "ser-humano", são necessárias outras, diversas e mais complexas ações, como o próprio documento destaca em (Figura 3):

FIGURA 3: O compromisso com a educação integral assumido pela penúltima versão da BNCC

\footnotetext{
A sociedade contemporânea impõe um olhar inovador e inclusivo

a questões centrais do processo educativo: o que aprender, para que aprender, como ensinar, como promover redes de aprendizagem colaborativa e como avaliar o aprendizado. No novo cenário mundial, comunicar-se, ser criativo, analítico-crítico, participativo, produtivo e responsável requer muito mais do que a acumulação de informações.
} 


\begin{abstract}
Aprender a aprender, saber lidar com a informação cada vez mais disponível, atuar com discernimento e responsabilidade nos contextos das culturas digitais, aplicar conhecimentos para resolver problemas, ter autonomia para tomar decisões, ser proativo para identificar os dados de uma situação e buscar soluções, são competências que se contrapõem à concepção de conhecimento desinteressado e erudito entendido como fim em si mesmo.
\end{abstract}

Fonte: BNCC, p. (17). Disponível emhttp://basenacionalcomum.mec.gov.br/images/BNCC_publicacao.pdf Acesso $16 / 10 / 2017$

Continuando com as análises dos conhecimentos gerais e actanciais pretendidos como essenciais para todo o aluno que passar pela Educação Básica, conforme propõe o documento analisado, identificamos, na apresentação das dez competências gerais, alguns assuntos tematizados e as ações depreendidas para seu tratamento, por meio das expressões nominais, para os temas, e verbais, para as ações. São eles (Figura 4):

FIGURA 4: As dez competências gerais eleitas pela penúltima versão da BNCC e os temas depreendidos

\begin{tabular}{|c|c|c|}
\hline & \multicolumn{2}{|c|}{ As 10 COMPETÊNCIAS GERAIS DA BNCC 2017} \\
\hline & \begin{tabular}{|c|} 
TEMAS \\
\end{tabular} & AÇÕES \\
\hline $1^{2}$ & $\begin{array}{l}\text { Conhecimentos históricos do mundo físico, } \\
\text { social, cultural e sociedade solidária. }\end{array}$ & valorizar, utilizar, colaborar (para a construção). \\
\hline $2^{a}$ & Curiosidade intelectual da ciência & $\begin{array}{l}\text { exercitar (a curiosidade), recorrer (às abordagens científicas), } \\
\text { investigar, refletir, analisar criticamente, ser criativo, elaborar e } \\
\text { testar(teses), formulare resolver (problemas), inventar } \\
\text { (soluções). }\end{array}$ \\
\hline $3^{\mathbf{a}}$ & Manifestações Artísticas & Valorizar, fruir, participar(de práticas). \\
\hline $4^{a}$ & $\begin{array}{l}\text { Linguagem verbal (oral e escrita) e verbo- } \\
\text { visual(libras) }\end{array}$ & Utilizar, expressar, partilhar, produzir(sentidos). \\
\hline $5^{\mathbf{a}}$ & Tecnologias Digitais de Comunicação & $\begin{array}{l}\text { utilizar (de forma reflexiva), comunicar, acessar, disseminar, } \\
\text { produzir (conhecimento), resolver (problema). }\end{array}$ \\
\hline $6^{2}$ & $\begin{array}{l}\text { Diversidade de saberes e experiências, mundo } \\
\text { do trabalho, projeto de vida pessoal, } \\
\text { profissional e social }\end{array}$ & valorizar-se, apropriar-se, entender, fazer (escolhas). \\
\hline $7^{2}$ & $\begin{array}{l}\text { Direitos Humanos e Consciência } \\
\text { Socioambiental }\end{array}$ & $\begin{array}{l}\text { argumentar, formular, negociar, defender (ideias), cuidar(de si e } \\
\text { dos outros) }\end{array}$ \\
\hline $8^{\mathbf{a}}$ & Saúde Física e Emocional & conhecer-se, apreciar-se, cuidar-se, lidar (com pressões do grupo). \\
\hline $9^{a}$ & $\begin{array}{l}\text { Diversidade de indivíduos e grupos sociais, } \\
\text { etnia, gênero, orientação sexual, idade, } \\
\text { convicção religiosa }\end{array}$ & $\begin{array}{l}\text { exercitar(empatia), respeitar, reconhecer-se (como parte), } \\
\text { comprometer-se }\end{array}$ \\
\hline $10^{\mathrm{a}}$ & $\begin{array}{l}\text { Princípios éticos, democráticos, inclusivos, } \\
\text { sustentáveis e solidários }\end{array}$ & agir, tomar decisões. \\
\hline
\end{tabular}

Fonte: de autoria das próprias autoras

A partir do quadro acima, constatamos que os temas nos remetem a uma diversidade de práticas sociais: ciência, arte, tecnologias digitais de comunicação, trabalho, direito, psicologia e religião, conquanto, percebemos que algumas não são citadas e que se fazem presentes na vida dos alunos como, por exemplo, as práticas cotidianas e a midiática em seus formatos mais acessíveis (impresso e televisivo). Em relação aos verbos, constatamos a menção a 37 tipos de ações, considerando que alguns deles se repetem na descrição das competências: cuidar (2); exercitar (2); formular (2); produzir (2); resolver (2); utilizar (3); valorizar (3).

Há de se destacar que, analisando tais competências gerais, constata-se o direcionamento prescritivo para a contemplação de diferentes ações interacionais com o outro e com os objetos materiais ou simbólicos construídos sócio-historicamente (valorizar/utilizar/colaborar para a construção). Já os temas, embora estejam na condição de objeto do verbo, são os protagonistas, aqueles que devem ser priorizado, entretanto, ficam as perguntas: como valorizar? Como utilizar os conhecimentos histórico-culturais de modo que a escola não seja um espaço monocultural e etnocentrista? Quem fará isso? Dessa forma, o fato de esses conhecimentos serem mencionados é importante, mas ainda falta uma maior clareza sobre a multiplicidade desses conhecimentos num país tão rico culturalmente, entre outros aspectos (como/quem/para quê?).

Novamente retomando a perspectiva curricular democrática e inclusiva freiriana, frente a tais afirmações e questionamentos, frisamos a importância de os currículos e das bases que os 
orientam, como é o caso da BNCC, não privilegiarem os fragmentos de apenas uma única realidade, ao contrário, devem eles promover e permitir uma ampla e diversa visão dela. Ademais, tendo em vista a extensão territorial e cultural brasileira, é de extrema importância que isso ocorra, caso contrário, pontos de vista preconceituosos, centralizadores e excludentes serão inevitáveis nos processos de interpretação e implementação das prescrições de modo geral.

Mediante as dez competências gerais prescritas pela BNCC e os questionamentos direcionados para a contemplação basilar da diversidade histórico-cultural, avançaremos em direção à seção destinada à disciplina de Língua Portuguesa para averiguarmos como tais competências (temas e ações) e princípios educacionais (formação humana integral e construção de uma sociedade justa, democrática e inclusiva) são transpostos para esse ensino específico.

A seção de Língua Portuguesa é apresentada da página 63 à 150 e, já no início, é apresentado objetivo da disciplina (Figura 5):

FIGURA 5: O objetivo da disciplina de Língua Portuguesa constante na penúltima versão da BNCC

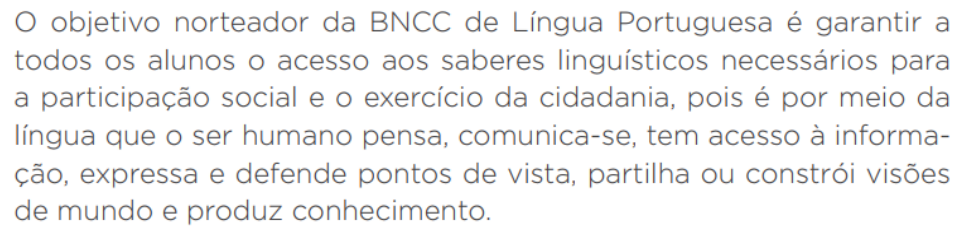

Fonte: BNCC, p. 63. Disponível em http://basenacionalcomum.mec.gov.br/images/BNCC_publicacao.pdf Acesso $16 / 10 / 2017$

Nesse momento, notamos que o foco da disciplina de Língua Portuguesa é o acesso aos saberes linguísticos. Devido à ausência de esclarecimentos do que venham a ser tais saberes, hipotetizamos que há uma redução do fenômeno linguageiro, de sua dimensão ideológica e de suas variadas realizações. Compreendemos que o homem, coletivamente, constrói variadas formas de comunicação e mobiliza diferentes saberes linguísticos que estão intimamente ligados aos contextos de uso e não a uma forma padrão e única. Os saberes linguísticos, dessa forma, estão a serviço dos usos e não o contrário, como interpreta a penúltima versão da BNCC, a língua é considerada em suas dimensões escrita e oral, conforme exposto na Figura 6:

FIGURA 6: As dimensões escrita e oral da língua conforme a penúltima versão da BNCC

A língua tem duas dimensões: é oral e escrita. Assim, sua aprendizagem considera o contínuo entre oralidade e escrita: na alfabetização, em que o oral é representado por notações (letras e outros signos), nos usos sociais da língua oral e nos usos sociais da leitura e da escrita - nas práticas de letramento. A meta do trabalho com a Língua Portuguesa, ao longo do Ensino Fundamental, é a de que crianças, adolescentes, jovens e adultos aprendam a ler e desenvolvam a escuta, construindo sentidos coerentes para textos orais e escritos; a escrever e a falar, produzindo textos adequados a situações de interação diversas; a apropriar-se de conhecimentos e recursos linguísticos - textuais, discursivos, expressivos e estéticos - que contribuam para o uso adequado da língua oral e da língua escrita na diversidade das situações comunicativas de que participam.

Fonte: BNCC, p. 63. Disponível em http://basenacionalcomum.mec.gov.br/images/BNCC_publicacao.pdf Acesso $16 / 10 / 2017$

Apesar de, nesse trecho, a implicação social ser levada em consideração nas metas estipuladas para o ensino da escrita e da oralidade, assim como também vimos na figura 5, o objeto de ensino de Língua Portuguesa altera-se em comparação às propostas dos PCN's, documento que até então 
cumpria o papel de nos dar as bases curriculares. Não é mais proposto o ensino de textos a partir de seus respectivos gêneros textuais, em outras palavras, em suas implicações sociais e ideológicas, como também constatam Cordeiro (2017), Rojo (2017) e Bueno, Jacob e Zani (2017 - no prelo). Vejamos (Figura 7):

FIGURA 7: O texto como objeto de ensino de Língua Portuguesa de acordo com a penúltima versão da BNCC

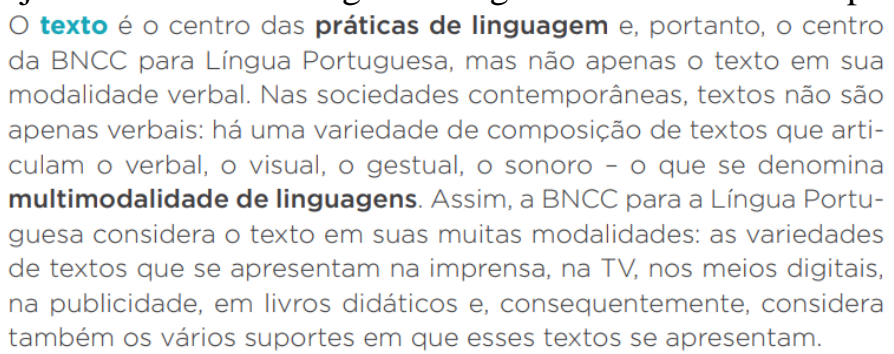

Fonte: BNCC, p. 63. Disponível em http://basenacionalcomum.mec.gov.br/images/BNCC_publicacao.pdf Acesso em $16 / 10 / 2017$

Bueno, Jacob e Zani (2017 - no prelo) questionam-se, ao se depararem com esses objetos e objetivos de ensino, se apenas uma dimensão dos textos deverá ser explorada, já que se afirma anteriormente, que o ensino de língua portuguesa deverá dar acesso apenas aos saberes linguísticos. Deve-se excluir, portanto, as demais? As autoras ainda apontam para as esferas discursivas que são contempladas no trecho acima: imprensa, publicidade e escolar. Apenas elas seriam suficientes, visto a defesa da formação integral dos alunos para a formação de uma sociedade mais democrática, inclusiva e justa? Tais esferas seriam satisfatórias no desenvolvimento das dez competências gerais defendidas para a Educação Básica e suas 37 ações correspondentes, bem como, para a contemplação das variadas situações comunicativas que os alunos participam e virão a participar, como proposto como meta do ensino da oralidade e da escrita? Continuemos nossas análises.

$\mathrm{O}$ documento organiza a proposta de ensino de Língua Portuguesa para os anos finais do Ensino Fundamental em cinco eixos: Oralidade, Leitura, Escrita, Conhecimentos linguísticos e gramaticais, Educação Literária. Quando apresentados tais eixos separadamente, explicitam-se as unidades temáticas, os objetos de conhecimento e as habilidades apresentadas para cada um dos nove anos do Ensino Fundamental.

Em relação à oralidade, não há menção aos gêneros de textos orais; são enfatizadas apenas suas diferenças com a escrita, desatendendo as relações de continuidade entre fala e escrita, conforme Marcuschi (2003), além das questões de variação linguística. Constatamos que a adequação do uso da linguagem às várias situações é mencionada, entretanto, qual o modo de fazê-lo se não pela escolha de um gênero oral, que é a base para a orientação da ação discursiva, como atesta Schneuwly (2010). É inquestionável que a adequação da oralidade à situação comunicativa só será possível se houver apropriação do uso dos gêneros por parte do aprendiz. Na penúltima versão da BNCC, ignoram-se ainda as discussões de diversos pesquisadores (Dolz; Schneuwly, 2010; Bueno; Costa-Hubes, 2015, entre outros) e dos próprios PCN's que enfatizavam a importância dos gêneros orais na formação cidadã e de um trabalho efetivo com eles na escola.

A proposta dessa versão da BNCC para a oralidade é a seguinte (Figura 8):

FIGURA 8: A oralidade na penúltima versão da BNCC

A oralidade precede a escolaridade, sendo a forma natural de aprendizagem da lingua fora da escola, desenvolvendo-se desde muito cedo por meio das interaçőes familiares e sociais. Na escola, porém, a oralidade (a fala e a escuta) torna-se objeto de conhecimento - de suas caracteristicas, de seus usos, de suas diferenças em relação à língua escrita - e ainda objeto de desenvolvimento de habilidades de 


\begin{abstract}
uso diferenciado em situaçōes que demandam diferentes graus de formalidade ou atendimento a convençóes sociais. Assim, o eixo Oralidade inclui conhecimentos sobre as diferenças entre língua oral e lingua escrita e os usos adequados da oralidade em interaçőes formais e convencionais. Além disso, considerando que a língua oral năo é uniforme, pois varia em função de diferenças de registros - formais ou informais --, de diferenças regionais (relativamente numerosas na vastidăo do território nacional), de diferenças sociais (determinadas pelo pertencimento a esta ou àquela camada social) -, esse eixo inclui também conhecer as variedades linguísticas da língua oral e assumir atitude de respeito a essas variedades, o que é fundamental para que se evitem preconceitos linguisticos.
\end{abstract}

Fonte: BNCC, p. 63 e 64. Disponível em http://basenacionalcomum.mec.gov.br/images/BNCC_publicacao.pdf Acesso em $16 / 10 / 2017$

$\mathrm{Na}$ parte correspondente à disciplina de Língua Portuguesa para os anos finais do Ensino Fundamental II (6..$^{\circ}$ ao $9 .^{\circ}$ ano), os conhecimentos prescritos (as Habilidades) são organizados em quadros, pelos eixos: Oralidade, Leitura, Escrita, Conhecimentos linguísticos e gramaticais e Educação Literária. O eixo Oralidade é distribuído, em todos os anos escolares $\left(6 .^{\circ}\right.$ ao $\left.9 .^{\circ}\right)$, pelos temas: Interação discursiva/intercâmbio oral no contexto escolar; Funcionamento do discurso oral; Estratégias de escuta de textos orais em situações específicas de interação, Produção de textos orais em situações específicas de interação e Variação Linguística, como vemos a seguir (Figura 9):

FIGURA 9: A organização do eixo da oralidade nos anos finais do Ensino Fundamental na penúltima versão da BNCC

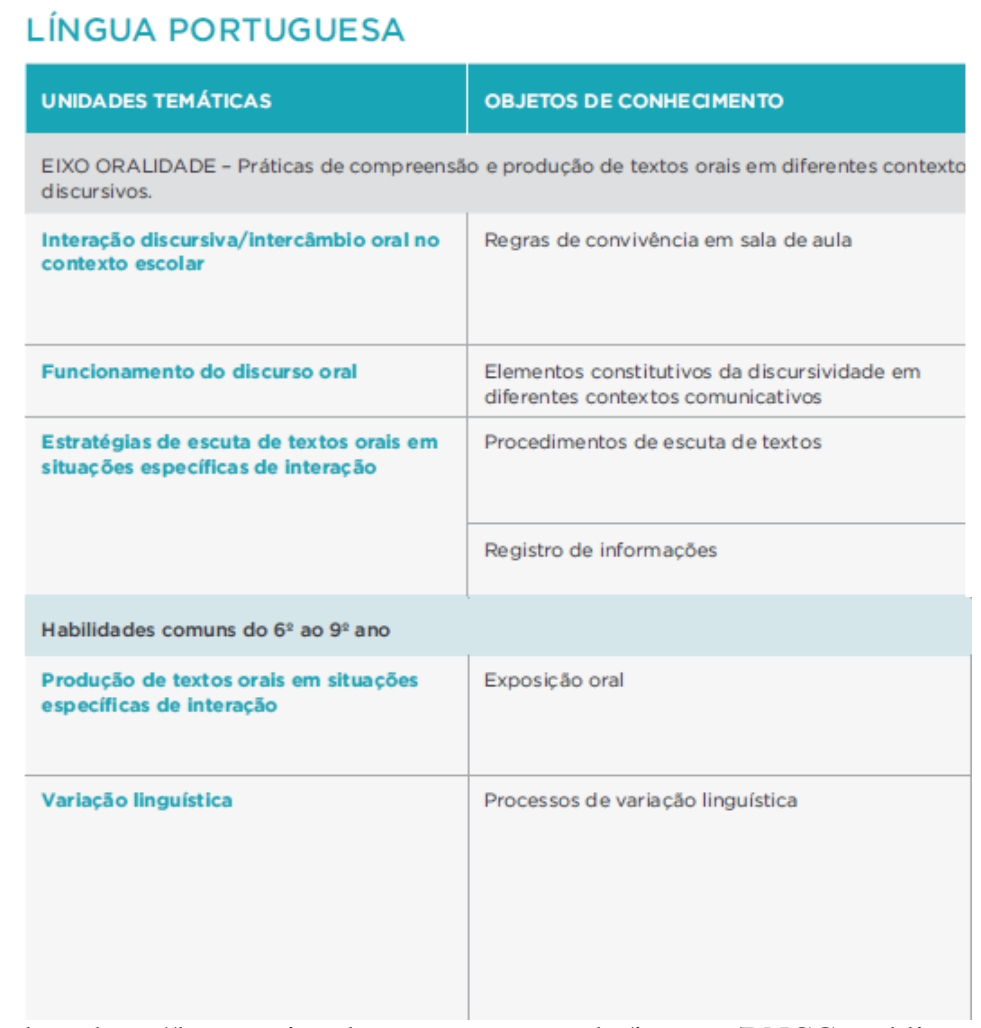

Fonte: BNCC, p. 116. Disponível em http://basenacionalcomum.mec.gov.br/images/BNCC_publicacao.pdf Acesso em $16 / 10 / 2017$ 
Conquanto não seja nosso objetivo de análise a verificação do ensino dos gêneros orais nos anos iniciais do Ensino Fundamental, é interessante destacar que há, para esse nível de ensino, uma distinção de abordagem do tratamento da oralidade, tanto no que diz respeito as suas características constituintes, quanto aos gêneros textuais orais. Identifica-se na penúltima versão da
BNCC para os anos iniciais, diferentemente dos anos finais, a tematização: das características da conversação espontânea, dos aspectos não linguísticos (paralinguísticos) no ato da fala, das finalidades da interação oral, dos gêneros textuais do discurso oral e das características da fala, como ilustram Bueno, Jacob e Zani (2017 - no prelo) no quadro (Figura 10) abaixo:

FIGURA10: Unidades temáticas e Objetos de Ensino de Língua Portuguesa nos anos iniciais do EF

\begin{tabular}{|c|c|c|c|c|c|c|}
\hline \multirow[t]{2}{*}{ Unidades temáticas } & \multicolumn{6}{|c|}{ Objetos de conhecimento } \\
\hline & & $1^{\circ}$ & $2^{\circ}$ & $3^{\circ}$ & $4^{\circ}$ & $5^{\circ}$ \\
\hline \multirow[t]{2}{*}{ Intera ção discursiva intercâmbio oral no contexto escolar } & $\begin{array}{l}\text { Constituição da } \\
\text { identidadepsicossocial, } \\
\text { em sala de aula, pormeio } \\
\text { da oralidade }\end{array}$ & $\mathrm{x}$ & $\mathrm{x}$ & $\mathrm{x}$ & $\mathrm{x}$ & $\mathrm{x}$ \\
\hline & $\begin{array}{l}\text { Regras de convivência } \\
\text { em sala de aula }\end{array}$ & $\mathrm{x}$ & $\mathrm{x}$ & $\mathrm{x}$ & $\mathrm{x}$ & $\mathrm{x}$ \\
\hline \multirow{5}{*}{ Funcionamento do discurso oral } & $\begin{array}{l}\text { Caracteristicas da } \\
\text { conversaçãoespontânea }\end{array}$ & $\mathrm{x}$ & $\mathrm{x}$ & $\mathrm{x}$ & $\mathrm{x}$ & \\
\hline & $\begin{array}{l}\text { Aspectos não linguísticos } \\
\text { (paralinguisticos)no ato } \\
\text { da fala }\end{array}$ & $\mathrm{x}$ & $\mathrm{x}$ & $\mathrm{x}$ & & \\
\hline & $\begin{array}{l}\text { Finalidades da interação } \\
\text { oral }\end{array}$ & & $\mathrm{x}$ & & & \\
\hline & $\begin{array}{l}\text { Gêneros textuais do } \\
\text { discurso oral }\end{array}$ & & & $\mathrm{x}$ & $\mathrm{x}$ & \\
\hline & Características da fala & & & & & $\mathrm{x}$ \\
\hline $\begin{array}{l}\text { Estratégias de escuta de textos orais em situações } \\
\text { especificas de interação }\end{array}$ & $\begin{array}{l}\text { Procedimentos de escuta } \\
\text { de textos }\end{array}$ & $\mathrm{x}$ & $\mathrm{x}$ & $\mathrm{x}$ & $\mathrm{x}$ & \\
\hline \multirow{2}{*}{$\begin{array}{l}\text { Produção de textos orais em situações específicas de } \\
\text { interação }\end{array}$} & Relato oral & $\mathrm{x}$ & $\mathrm{x}$ & $\mathrm{x}$ & & \\
\hline & Jomal fala do e entrevista & & & & $\mathrm{x}$ & $\mathrm{x}$ \\
\hline
\end{tabular}

Fonte: Bueno, Jacob e Zani (2017 - no prelo)

Frente a essa constatação de distinção de tratamento da oralidade nos diferentes anos do Ensino Fundamental, é válido questionar os possíveis motivos de se tematizar, na parte correspondente ao Funcionamento do Discurso oral, as características constituintes da oralidade e os próprios gêneros do discurso oral em determinada fase escolar e não em outra. Acredita-se que o trabalho mais direcionado nos anos iniciais dessas dimensões é suficiente, não precisando ser retomado nos anos finais? Por que tematizá-las em uma fase e não em outra? É bem provável que equipes diferentes elaboraram as orientações para os anos iniciais e finais do Ensino Fundamental, gerando, consequentemente, propostas distintas; entretanto, as orientações curriculares não deveriam propor um desenvolvimento espiral e progressivo dos saberes, competências e habilidades? Estipular os gêneros textuais a serem ensinados poderia gerar um efeito castrador nas práticas pedagógicas, mas deixar de citá-los como importantes objetos de ensino, ou ao menos sugerir aqueles que são semelhantes na organização textual e discursiva, como fazem Dolz e Schneuwly (2010) ou, até mesmo, pertencentes a semelhantes esferas de circulação, seria de notória importância.

Como forma de facilitar a análise da proposta das habilidades correspondentes ao ensino da oralidade na disciplina de Língua Portuguesa nos anos finais do Ensino Fundamental e, também, para ficar clara a proposta de progressão curricular, teceremos nossas considerações obedecendo à ordem dos temas mencionados para essa fase de ensino.

No que compete ao tema "Interação discursiva/intercâmbio oral no contexto escolar", em todos os anos, as habilidades visaram a propor as ações almejadas para que fossem atendidas às "Regras de convivência em sala de aula". Como podemos constatar nesses títulos temáticos, as ações correspondem à adequação da fala do aluno ao contexto de sala de aula. Há nesse momento uma 
aparente sugestão de progressão, as formas do falar vão se complexificando, passando de posições mais passivas para mais respeitosas, ativas, colaborativas e argumentativas. Os gêneros orais mencionados são, no $6 .^{\circ}$ ano, Fóruns e Enquetes e, nos $8 .^{\circ}$ e $9 .^{\circ}$ anos, Debate Controverso e Polêmico, não há menção de gêneros orais para o $7 .^{\circ}$ ano. Com tais constatações, embora já saibamos que objeto de ensino de Língua Portuguesa declarado pela penúltima versão da BNCC é o texto, supomos que tais gêneros serão retomados nos demais temas da Oralidade, uma vez que o domínio de suas características constituintes é exigido no próprio documento para interação discursiva no contexto escolar: estratégias conversacionais $\left(6 .^{\circ}\right.$ e $\left.7 .^{\circ}\right)$, adequação oral das respostas e justificativas ao contexto $\left(7^{\circ}\right)$, manifestação de opiniões respeitando o turno das falas $\left(7 .^{\circ}\right.$ e $\left.9 .^{\circ}\right)$, participação nas interações de modo a exercitar a escuta respeitável $\left(8 .^{\circ}\right)$, apresentação de argumentos e contraargumentos coerentes, respeitando os turnos de fala $\left(8 .^{\circ}\right)$, apresentação de forma clara particularmente quando suas posições forem divergentes das de seus interlocutores $\left(9^{\circ}\right)$.

Em relação ao tema "Funcionamento do Discurso Oral", as habilidades requeridas são especificadas em todos os anos escolares $\left(6 .^{\circ}\right.$ ao $\left.9 .^{\circ}\right)$ como "Elementos constitutivos da discursividade em diferentes contextos sociais". Ao contrário do que prevíamos, não há menção aos gêneros orais citados anteriormente. As habilidades a serem desenvolvidas são (Figura 11):

FIGURA 11: Habilidades almejadas no trabalho com o "Funcionamento do Discurso Oral" na BNCC

\begin{tabular}{|c|c|c|c|}
\hline \multirow{5}{*}{$\begin{array}{l}\text { Funcionamento do } \\
\text { discurso oral }\end{array}$} & \multirow{5}{*}{$\begin{array}{c}\text { Elementos constitutivos da } \\
\text { discursividade em diferentes } \\
\text { contextos comunicativos }\end{array}$} & 60 & $\begin{array}{l}\text { (EF06LP03) Interagir, oralmente, na escola e fora dela, considerando o contexto, a funç̧ão social e a } \\
\text { finalidade da interação. }\end{array}$ \\
\hline & & 70 & $\begin{array}{l}\text { (EF07LP03) Utilizar estratégias de construção do texto oral, considerando os objetivos comunicativos e o } \\
\text { contexto. }\end{array}$ \\
\hline & & 80 & $\begin{array}{l}\text { (EF08LP03) Justificar, em interaçôes orais, mudança, desvio ou quebra de tópico conversacional, } \\
\text { analisando estratégias de retomada do tema da interação. }\end{array}$ \\
\hline & & 9으 & \begin{tabular}{|l} 
(EF09LP03) Utilizar estratégias de construção do texto oral, considerando os objetivos comunicativos, o \\
contexto e a situação e as características dos interlocutores.
\end{tabular} \\
\hline & & 9으 & $\begin{array}{l}\text { (EF09LP04) Justificar, em interaçôes orais, mudanç̧a, desvio ou quebra de tópico conversacional, } \\
\text { analisando estratégias de retomada do tema da interação. }\end{array}$ \\
\hline
\end{tabular}

Fonte: de autoria das próprias autoras

Percebemos, diante desse quadro, que, na exposição das habilidades correspondentes ao Funcionamento do discurso oral ao longo dos quatro anos, não há a especificação dos diferentes contextos comunicativos como declarado no subtema, o que nos leva a interpretar que a penúltima versão da BNCC considera que as habilidades do falar, da oralidade, são as mesmas em quaisquer situações. Algumas questões surgem com essa abordagem: quais contextos "fora" da escola estão sendo privilegiados, já que não são explicitados? A qual "construção do texto oral" o documento se refere: ao debate regrado, ou à apresentação oral, ou ao jornal televisionado, etc.? Quais tipos de "interações orais" se referem para propor que os alunos desenvolvam habilidades como a "quebra do tópico conversacional" e a "estratégia de retomada do tema"? Todas as interações orais necessitam de tais estratégias? Os objetivos comunicativos sempre são os mesmos nas expressões orais? Enfim, acreditamos que, quando não se declara o Gênero Oral e os diferentes contextos comunicativos, dogmatiza-se a constância dos recursos da oralidade indiferentemente das situações específicas de comunicação, dando a possibilidade de interpretações estruturalistas, isentas dos contextos de uso. Poderá haver, desse modo, a ênfase da forma em detrimento de sua dependência ideológica e contextual, reverberando nos materiais didáticos, nos cursos de formação docente e nos modos de ensinar.

Quanto ao tema "Estratégia de Escuta de textos orais em situações específicas de interação", são apresentadas habilidades específicas do "Procedimento de escuta de texto" e do "Registro de Informações". Como o próprio tema sugere, é almejado que o aluno se comporte como ouvinte, como plateia nas seguintes situações comunicativas: 6. ${ }^{\circ}$ ano - exposições, palestras, noticiário radiofônico ou televisivo, etc.; $7 .^{\circ}$ ano - palestras, noticiários radiofônicos e televisivos, etc; $8 .^{\circ}$ e $9 .^{\circ}$ anos - entrevista, debates (televisivo, em sala de aula, em redes sociais etc.). As habilidades requeridas para o desenvolvimento das estratégias de escuta de textos orais correspondem a diferentes atitudes do aluno frente às temáticas ouvidas. Aparentemente, as habilidades são expostas, ao longo dos anos, propondo uma progressão: $6 .^{\circ}$ ano - 
distinguir fato e opinião e registrar informações principais; $7 .^{\circ}$ ano - distinguir fato e opinião, identificar informações implícitas e explícitas e registrar informações principais em apresentações orais; $8 .^{\circ}$ ano - analisar posicionamentos defendidos e refutados, além de parafrasear ideias principais e secundárias; $9 .^{\circ}$ ano - justificar os pontos de vista defendidos e refutados, bem como sintetizar com base nas informações. Diante da variedade de situações comunicativas sugeridas nos diferentes anos escolares, as quais, supõe-se, que o aluno virá a participar, e das diferentes habilidades do escutar e do registrar, ficam as perguntas: uma vez que, como constatamos, a penúltima versão da BNCC não assume os gêneros orais como objetos de ensino, assim como suas características constituintes, como será possível aos alunos depreendê-los, compreender suas funcionalidades e assumirem uma atitude responsiva e crítica frente a eles? Os alunos conseguirão, portanto, desenvolver as habilidades de escuta e registro frente a essa problemática?

A proposta da temática "Produção de textos orais em situações específicas de interação" (Figura 12) dirige-se de igual maneira a todos os anos finais do Ensino Fundamental II, o que nos leva a constatar a ausência de uma progressão curricular.

FIGURA 12: Habilidade Comum do $6 .^{\circ}$ ao $9 .^{\circ}$ ano para a Produção de textos orais em situações específicas de interação - BNCC 2017

\begin{tabular}{|c|c|l|}
\hline $\begin{array}{c}\text { Produção de textos orais em } \\
\text { situações específicas de } \\
\text { interação }\end{array}$ & $\begin{array}{l}\text { Exposição Oral } \\
\text { colabor) Expor, no tempo previsto, resultados de pesquisa ou estudo, em grupo, com apoio de quadros, tabelas ou gráficos e uso de } \\
\text { recursos de tecnologias da informação e comunicação, adequando vocabulário, } \\
\text { pronúncia, entonação, gestos, pausas e ritmo. }\end{array}$ \\
\hline
\end{tabular}

Fonte: BNCC, p. 116 e 117. Disponível em http://basenacionalcomum.mec.gov.br/images/BNCC_publicacao.pdf Acesso em 16/10/ 2017

A divergência verificada entre o que se propõe deve-se, primeiramente, à forma plural na expressão "textos orais" quando, na verdade, é indicada, de modo pouco definido, apenas a "Exposição Oral". Qual o tipo de exposição oral? Correspondente a qual contexto? Tais questões não são claras. Além dessa problemática, a única prática social privilegiada na proposta é a escolar, pois é pretendido que o aluno seja capaz, ao longo dos quatro anos, de expor resultados de pesquisa e estudo, o que, mais uma vez, destoa do que é tematizado na forma plural "Produções de textos orais em situações específicas de interação". Há, como podemos averiguar, uma simplificação e redução dos usos da oralidade quando são priorizados a esfera escolar e os objetivos comunicacionais escolares. Isto posto, a penúltima versão da BNCC, quando idealiza o eixo da Oralidade, em especial, a produção oral, não possibilita a formação do indivíduo em sua integridade, uma vez que fornece a ele o ensino de apenas uma forma, das muitas, de expressão oral.

A ausência da pluralidade e especificidade das práticas sociais privilegiadas nesse documento, bem como, a desconsideração dos gêneros orais como objetos de ensino, principalmente, nos quesitos Produção de textos orais e Funcionamento do discurso oral, sugerem um conflito interpretativo em relação à temática "Variação Linguística" proposta, de igual modo, para todos os anos $\left(6 .^{\circ}\right.$ ao 9..$^{\circ}$.

FIGURA 13: Habilidades Comuns do $6^{\circ}$ ao $9^{\circ}$ ano para o tema Variação Linguística - BNCC 2017

\begin{tabular}{|c|c|c|}
\hline \multirow{4}{*}{$\begin{array}{l}\text { Variação } \\
\text { Linguistica }\end{array}$} & \multirow{4}{*}{$\begin{array}{l}\text { Processos de variação } \\
\text { linguistica }\end{array}$} & $\begin{array}{l}\text { (EF69LP02) Justificar fatores determinantes de registro linguístico (formal, informal), } \\
\text { como: contexto, ambiente, tema, estado emocional do falante, grau de intimidade } \\
\text { entre os falantes. }\end{array}$ \\
\hline & & $\begin{array}{l}\text { (EF69LPO03) Adequar o nivel de formalidade da fala aos temas, contextos/situações, } \\
\text { interlocutores. }\end{array}$ \\
\hline & & $\begin{array}{l}\text { (EF69LP04) Reconhecer a manifestação de preconceitos linguisticos como formas de } \\
\text { discriminação e dominação. }\end{array}$ \\
\hline & & \begin{tabular}{|l|} 
(EFG9LL05) Respeitar a variacẵo linguística por características sociais, regionais, \\
urbanas e rurais da fala, rejeitando preconceitos linguísticos.
\end{tabular} \\
\hline
\end{tabular}

Fonte: BNCC, p. 116 e 117. Disponível em http://basenacionalcomum.mec.gov.br/images/BNCC_publicacao.pdf Acesso em 16/10/ 2017

Como contemplar as habilidades propostas para o trabalho com os Processos de variação 
linguística se aos alunos, conforme a documento recomenda em outros temas da Oralidade, não são oferecidas possibilidades de circulação em diferentes lugares e o conhecimento de modos de se falar específicos de cada situação, de cada gênero oral?

Há, no texto da penúltima versão BNCC, proposições que não se cumprem no próprio documento. Assume-se como direcionamentos as dez competências gerais, a educação integral dos indivíduos, a formação democrática, inclusiva e justa, no entanto, os temas e as habilidades elencadas para o ensino da oralidade não cumprem tais objetivos. Verifica-se, por conseguinte, a redução e simplificação dos importantes papéis sociais da oralidade, de seu potencial desenvolvimentista, bem como da complexidade da discursividade oral.

\section{Considerações finais}

As análises expostas e discutidas neste artigo nos permitiram, primeiramente, identificar a ausência dos professores e demais profissionais da educação no processo de elaboração da penúltima versão da BNCC, o que contraria as vozes de autoridade recorridas pelos próprios elaboradores para legitimação legal do documento: a LDB e o PNE, e os próprios princípios assumidos por ela: a formação de uma sociedade mais justa, inclusiva e democrática. A não implicação dos professores no processo de construção e discussão das prescrições de seu próprio trabalho, cabendo a eles apenas a execução, sem consulta ou questionamento, com o objetivo maior de garantir os bons resultados em avaliações externas, nos remetem à concepção de trabalho taylorista. Ao trabalhador é vetado o conhecimento da complexidade e completude de todo o processo produtor, sendo responsável apenas por executar específicas tarefas, exercendo, desse modo, um trabalho alienado e, por conseguinte, afetando sua saúde e tolhendo seu potencial criativo. Trata-se, portanto, de um documento construído numa coletividade selecionada e, desse modo, uma perspectiva freireana de que o currículo deve ser um produto e instrumento da coletividade é, na verdade, descartada.

Em relação às diretrizes propostas para a disciplina de Língua Portuguesa dos anos finais do Ensino Fundamental, mais especificamente, aquelas destinadas aos gêneros orais, pode-se afirmar que é mencionada a necessidade de se considerar a diversidade de práticas sociais em que a fala esteja envolvida, bem como sua adequação aos objetivos comunicacionais e aos interactantes da situação enunciativa. Conquanto há algumas divergências entre tais ideais e o que é exigido como resultados das aprendizagens (as habilidades). Em primeiro lugar, as práticas sociais de uso da linguagem citadas restringem-se às esferas midiática e escolar; em vista disso, como contemplar a diversidade proposta? Em segundo lugar, alguns gêneros orais são citados, entretanto, nenhum deles assume o lugar de objeto de ensino. Ao aluno é estipulado que demonstre domínio das características constituintes desses objetos, mas como tornar isso possível se não são propostos para o ensino? Em terceiro lugar, por não se levar em conta os gêneros orais, os meios possíveis para a realização da discursividade oral, o documento toma as características da oralidade como comuns a quaisquer situações comunicativas, não as diferenciando conforme o contexto e a implicação ideológica.

Pelo que nos é apresentado nessa versão da BNCC, parece não haver espaços para o desenvolvimento da voz do aluno, dado que as possibilidades de ação pela fala são restritas. Não são dadas condições para que ele circule em diferentes situações, exercendo diferentes papeis (apresentador, expositor, debatedor, defensor, crítico, mediador, conciliador, etc), para que conquiste diferentes objetivos pelos usos da fala e para que, assim, desenvolva-se integralmente. O ensino do oral, bem como o da escrita, precisa ser proposto vislumbrando o desenvolvimento de sujeitos capazes de fomentar, verdadeiramente, uma sociedade mais justa, democrática e inclusiva.

As discussões e considerações tecidas neste artigo, apesar de fazerem referência a uma versão, felizmente, obsoleta da BNCC, revelam a extrema necessidade de continuarmos com uma vigilância acirrada das prescrições educacionais, pois são elas que, ao longo do tempo, modificam direta e indiretamente as representações sociais do trabalho educacional, de sua forma de execução e de formação; além de outros efeitos sentidos na produção e distribuição de materiais didáticos e das ideologias disseminadas por eles, por exemplo. Ademais, acreditamos que análises como as realizadas neste artigo e as aquelas citadas ao longo dele (MACHADO; BRONCKART, 2009; ALVES, 2014; CORDEIRO, 2017; ROJO, 2017; BUENO; JACOB; ZANI, 2017 - no prelo; FREITAS, 2017) exerceram papel fundamental para que significativas alterações fossem efetivadas no documento homologado em dezembro de 2017, 
principalmente, no que tange às propostas pedagógicas englobantes e ao ensino de Língua Portuguesa, que retoma os gêneros textuais como os verdadeiros objetos de ensino.

\section{Notas}

1. Le processus d'appropriation d'un artefact s'accompagne, chez le sujet, de constructions représentatives relatives à l'instrument, à la réalité... Il s'accompagne aussi de l'élaboration de structures permettant l'organisation de l'action du sujet : les schèmes d'utilisation (RABARDEL, 1995, p. 63).

2. L'unité d'analyse est l'action médiatisée par le langage: une séquence organisée d'événements imputables à un agent auquel peuvent être attribués des motifs (représentations rétroactives des raisons d'agir) et des intentions (représentations proactives de l'effet de l'action) (BRONCKART, 2017a, p. 33).

\section{Referências}

ALVES, N. Sobre a possibilidade e a necessidade curricular de uma base nacional comum. Revista eCurriculum [en linea], 12 (Octubre-Diciembre): [Fecha de consulta: 21 de octubre de 2017] Disponible

en: $<$ http://www.redalyc.org/articulo.oa?id=7663290 4003> ISSN 1809-3876. 2014.

AMIGUES, R. Trabalho do professor e trabalho de ensino. In: A. R. Machado (Org.) O ensino como trabalho. Uma abordagem discursiva. Londrina. Eduel: 2004, (p. 35-53) 325p.

BAKHTIN, M. (VOLOCHINOV, V. N.). Marxismo e Filosofia da Linguagem. Trad. Michel Lahud e Yara F. Vieira. $3^{a}$ edição. São Paulo: Editora HUCITEC. 1986.

BRASIL, MEC. Lei de Diretrizes e Bases para Educação Nacional, n 9394/96, de 20 de dezembro de 1996.

BRASIL, SEF. Parâmetros Curriculares Nacionais. Ensino Fundamental e Médio: MEC/SEE. 1998.

BRONCKART. J.P. Atividade de Linguagem: discurso e desenvolvimento humano. Machado e Matencio (Trad). $1^{\text {a }}$. edição. Campinas: Mercado de
Letras, 2006.

BRONCKART, J-P. Atividade de Linguagem, textos e discursos: por um interacionismo sóciodiscursivo. Anna Rachel Machado, Pericles Cunha (Trad.). 2a edição. São Paulo: Educ. 1999.

BRONCKART, J. P. Développement du langage et développement psychologique. L'approche de l'interactionnisme socio-discursif. Veredas Interacionismo Sociodiscursivo - Volume 21, número 3, p. 30 - 46 - PPG Linguística/UFJF - Juiz de Fora (MG), 2017a - ISSN: 1982-2243

BRONCKART, J. P. La transposition didactique dans les interventions formations. In: Ruptures et continuités en éducation : aspects théoriques et pratiques. Ouagadougou: Presses universitaires. 2004.

BRONCKART, J.P. O Agir nos discursos: das concepções teóricas às concepções dos trabalhadores. Machado e Matêncio (Trad). Inserir edição. Campinas: Mercado de Letras. 2008.

BRONCKART, J.-P.; MACHADO, A. R.. Procedimentos de analise de textos sobre o trabalho educacional. In: MACHADO, A. R. (org.). O ensino como trabalho: uma abordagem discursiva.

Londrina: Eduel. 2004.

BRONCKART, J. P.; BULEA-BRONCKART. E. As unidades semióticas em ação: estudos linguísticos na perspectiva do Interacionismo Sociodiscursivo. Trad. Lousada, E., Bueno, L.; Guimarães, A. M. G. Inserir edição. Campinas: Mercado de Letras. 2017b.

BUENO, L.; JACOB, A. E.; ZANI, J. B. Gêneros orais na base nacional comum curricular (BNCC): uma análise dos anos iniciais. (2017 - no prelo)

BUENO, L.; COSTA-HÜBES, T. Gêneros Orais no Ensino. $1^{\text {a }}$. edição. Campinas: Mercado de Letras, 2015.

CLOT, Y. A Função Psicológica do Trabalho. Trad. Adail Sobral. $2^{\mathrm{a}}$. edição. - Petrópolis, RJ : Vozes, 2006.

CLOT, Y. Trabalho e o poder de agir. Trad. Guilherme João de Freitas Teixeira e Marlene Machado Zica Vianna. $1^{a}$. edição. Belo Horizonte. Fabrefactum, 2010. 
CORDEIRO, G. S. Mesa-redonda intermediária "Gêneros e participação em contexto educacional". In: IX SIGET. Campo Grande-MS. 2017.

DIOLINA, K. Quem ensina, aprende a vencer os desafios da profissão: o papel do coletivo. 2016. 238 p. (Doutorado em Linguística Aplicada e Estudos da Linguagem), Pontifícia Universidade Católica de São Paulo: São Paulo: 2016.

O professor temporário e o papel do coletivo: marcas da (des)vitalidade do métier. Revista de Estudos Linguísticos Veredas. Volume especial: O Interacionismo Sociodiscursivo. Volume 21, Número 3, p. 424 - 443 - PPG Linguística/UFJF - Juiz de Fora (MG), 2017 ISSN: 1982-2243.

DOLZ, J.; SCHNEUWLY, B. Gêneros orais e escritos na escola. Trad. Roxane Rojo e Glaís Cordeiro. $1^{\mathrm{a}}$. edição e $2^{\mathrm{a}}$. edição. Campinas, SP: Mercado de Letras, 2004 e 2010.

DOLZ, J.; SCHNEUWLY, B.; HALLER, S. O oral como texto: como construir um objeto de ensino. In: Gêneros Orais e Escritos na Escola. Tradução e Organização por Roxane Rojo e Glaís Sales Cordeiro. $2^{a}$ Edição. Campinas: Mercado de letras, 2010. p. 125-158.

FREITAS, L.C. BNCC: uma base para o gerencialismo-populista. Disponível em: https://avaliacaoeducacional.com/2017/04/07/bnccuma-base-para-o-gerencialismo populista/ Acesso em 02/out/2017.

MACHADO, A. R.; BRONCKART, J-P. (Re)configurações do trabalho do professor construídas nos e pelos textos. In: $O$ trabalho do professor em uma nova perspectiva. Machado, A. R. e colaboradores; Vera Lúcia Lopes Cristóvão, Lilia Santos Abreu-Tardelli (orgs): posfácio Jean-Paul Bronckart $-1^{\mathrm{a}}$. edição. Campinas, SP: Mercado de Letras (Série ideias sobre Linguagem), 2009.

MACHADO, A. R. Ensino de Gêneros Textuais para o desenvolvimento do professor e de seu trabalho. In: SERRANI, S. V. (Org.). Letramento, discurso e trabalho docente. $1^{\text {a }}$. edição. Editora Horizonte, 2010.

MARCUSCHI, L. A. Da fala para a escrita: atividades de retextualização. $4^{a}$ edição. São Paulo:
Cortez Editora. 2003.

MARCUSCHI, L. A. Produção textual, análise de gêneros e compreensão. $3^{\text {a }}$. edição. São Paulo: Parábola Editorial, 296 p., 2008.

MENEZES, M. G. de; SANTIAGO, M. E. Contribuição do pensamento de Paulo Freire para o paradigma curricular crítico-emancipatório. ProPosições, v. 25, n. 3 (75), p. 45-62, set./dez. 2014.

RABARDEL, P. Les hommes et les technologies : approche cognitive des instruments contemporains. Armand Colin, pp.239, 1995.

Le langage comme instrument? Éléments pour une théorie instrumentale élargie. In: CLOT, Y. (Org.). Avec Vygostski. $2^{\mathrm{a}}$ Edição. p. 343, La Dispute, Paris, 2002.

ROJO, R. Mesa-redonda intermediária "Gêneros e participação em contexto educacional". In: IX SIGET. Campo Grande-MS., 2017.

SCHNEUWLY, B. Palavras e Ficcionalização: um caminho para o ensino da linguagem oral. In: Gêneros Orais e Escritos na Escola. Tradução e Organização por Roxane Rojo e Glaís Sales Cordeiro. $2^{a}$ Edição. Campinas: Mercado de letras, 2010. p. 109-124.

SCHNEUWLY, B. Gêneros e tipos de discurso: considerações psicológicas e ontogenéticas. In: Gêneros Orais e Escritos na Escola. Tradução e Organização por Roxane Rojo e Glaís Sales Cordeiro. $1^{a}$ Edição. Campinas: Mercado de letras, 2004 p. 109-124.

STREET, B. V. Os novos estudos sobre o letramento: histórico e perspectivas. In: MARINHO, M.; CARVALHO, G.T. (orgs.). Cultura escrita e letramento. Belo Horizonte: Editora UFMG, 2010.

VOLOCHINOV, V. N. Marxismo e Filosofia da Linguagem. Trad. Michel Lahud e Yara F. Vieira. $3^{\text {a }}$ edição. São Paulo: Editora HUCITEC. 1986.

SAUJAT, F.. O trabalho do professor nas pesquisas em educação: um panorama. In: MACHADO, A. R. (Org.). O ensino como trabalho: uma abordagem discursiva. São Paulo, Contexto, 2004. 


\section{Sobre as autoras}

Ana Elisa Jacob: Doutoranda em Educação, linguagens e processos interativos pela Universidade São Francisco - Itatiba/SP (bolsista Capes). Mestre em Linguística Aplicada e Estudos da Linguagem pela PUC-SP (bolsista CNPq). Membro dos grupos ALTER-LEGE-USF/CNPq e ALTER-Age/USP. Desenvolve pesquisas relacionadas ao ensino-aprendizado de gêneros textuais sob as óticas do Interacionismo Sociodiscursivo e dos Letramentos Sociais.

Kátia Diolina: Pós-doutoranda (CAPES-PNPD) na Universidade São Francisco em Educação. Doutora e mestre $(\mathrm{CNPq})$ pelo Programa de pós-graduação em Linguística Aplicada e Estudos da Linguagem na PUC-São Paulo. Investiga e intervém junto à formação inicial e continuada segundo a Clínica da Atividade e a ergonomia francófona. Desenvolve pesquisas relativas ao processo de ensino e aprendizagem dos gêneros textuais no âmbito do Ensino Superior em prol do letramento acadêmico. Defende o papel central e decisivo da linguagem na formação e no desenvolvimento do homem dado o seu caráter interacionista, sociocultural, histórico e ideológico.

Luzia Bueno: Professora do Programa de Pós-Graduação Stricto Sensu em Educação da Universidade São Francisco - Itatiba/ SP. Realizou Pós-doutorado no IEL, Unicamp, sob supervisão de Angela Kleiman. Graduada em Letras e Ciências Sociais pela Unicamp. Mestre em Linguística Aplicada pela UNICAMP. Doutora em Linguística Aplicada e Estudos da Linguagem pela PUC-SP. Realizou estágio doutoral na Universidade de Genebra sob supervisão de J.-P. Bronckart. Líder do grupo ALTER-LEGE-USF/CNPq e vice-líder do Grupo ALTER-Age/USP.

Recebido em novembro de 2017.

Aprovado em março de 2018. 